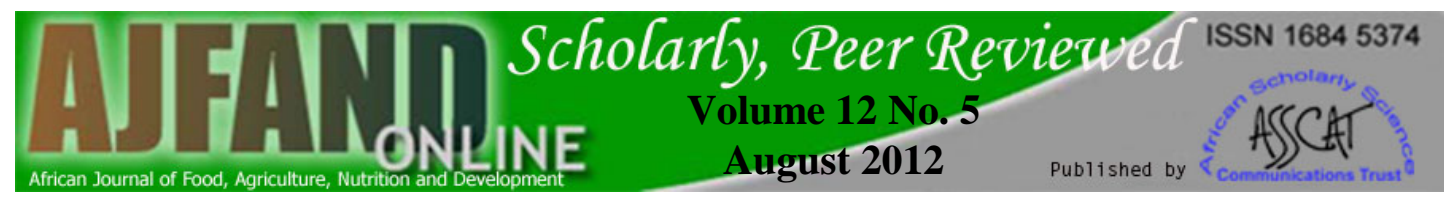

\title{
AGRICULTURAL PEST CONTROL PROGRAMMES, FOOD SECURITY
} AND SAFETY

\author{
Eze SC $^{1 *}$ and BC Echezona ${ }^{1}$
}

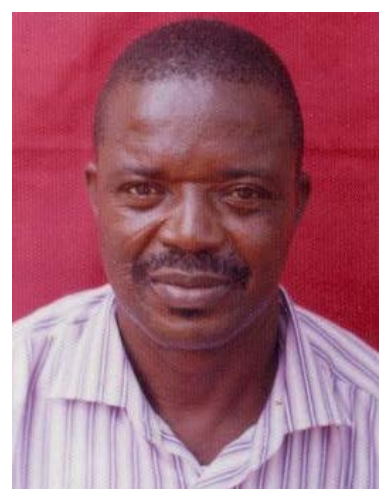

Simon Eze

*Corresponding author email: simoneze2002@yahoo.com

${ }^{1}$ Department of Crop Science, University of Nigeria, Nsukka 


\section{ABSTRACT}

Agricultural pest management control strategies are primarily concerned with food security and safety. Popular pest control methods include application of synthetic pesticides, biopesticides (plant extracts), non-chemical pest management and integrated pest management (IPM). The resistance of some of the pests to the chemical pesticides, coupled with potential health hazards on the environment gave birth to a search for botanicals as alternatives to synthetic pesticides. Botanicals as biopesticides were, though effective but their shelf lives and specific actions on the target organisms have not been determined. Non-chemical pest control methods involve common cultural practices which include crop rotation, tillage, and varying time of planting or harvesting, trap cropping which appear to be the best in terms of food safety and quality but the ability of this approach to reduce pest population may be minimal. Because no single pest control method can guarantee food security and safety, integrated pest management (IPM) approach appears to hold promise. The IPM is an ecologically based approach that combines all the available pest control methods to manage pest damage by the most economical means, with the fewest possible hazards to life, property and environment. However, this review shows that the impact of integrated pest management in the rural farm communities is low. In an era of growing consumer awareness and sophistication, food quality is being emphasized. Food safety means that the agro-products should be free from pesticide residues:- therefore, aspects of farm management such as sources of seeds and seedlings, pests and weed elimination, pesticide application dates, dates and amount of fertilization, harvesting or post harvest treatments and basic information regarding the individual farmer or marketing agents activities should be certified before consuming agricultural products. Federal governments especially in developing countries are advised to mount regulating Agencies that will be responsible for a number of activities that contribute to food security and safety, water quality and pesticide applicator training as practiced in the United States of America, India and Indonesia. The agencies will ensure that the public is protected from potential health risks posed by pesticide treated foods.

Key words: Pesticide, Food security, Food safety 


\section{INTRODUCTION}

Mankind is always in competition with insects for available natural resources and most importantly food and food crops. Insect pests and disease vectors are major threats to increased agricultural production and to the health and well-being of man and his/her livestock. Efforts to control arthropod pests and disease vectors relied primarily on the application of various synthetic pesticides which often caused undesirable side effects such as toxicological and environmental problems. Such problems include leaving toxic residues on food, soil and water, adverse effects on non-target insects and other beneficial organisms and development of resistant strains of insects [1]. Pesticides have been reported to be potential health hazards and a threat to food security globally [2]. Food and Agriculture Organization estimates that food demand will double by 2050 and to meet this demand, cereal yields in developing countries will have to increase by $40 \%$ and an additional 100-200 million hectares of land may be needed [3]. According to Rosegrant et al. cereal demand worldwide will rise by 56\% until 2050 when the population will have increased to over 8 billion [4].

Some pests are difficult to control with available technologies and large differences exist in the efficacy of pest control. In Northwest Europe, during 2001-2003, efficacy was as high as 71\%, in South Asia 42\%, in West Africa 43\% and in East Africa 32\% [5]. Pesticide residues are also a more frequent issue in developing countries due to higher pest pressure and subsequent overuse of pesticides, often of doubtful quality. Disposal of contaminated yields add to further decrease in crop productivity. The Food and Agriculture Organization reported that climate change is likely to increase pest pressure and the incidence of mycotoxins [6]. This paper therefore examines the diverse pest control management in relation to food security and safety.

\section{REVIEW}

\section{Use of synthetic pesticides.}

In a broad sense, pesticide is any agent used to kill or control undesired insects, weeds, rodents, fungi, bacteria or other organisms. Schillhorn, in his review of agricultural pest managements noted that in Asia, pesticides are often sold through unlicensed dealers and shopkeepers [7]. Some of these may be familiar with agrochemicals, but in many rural shops one may find pesticides sold next to food products such as milk or bread. Although the availability of pesticides in rural areas is important, the benefit of such availability has to be weighed against consumer safety, proper storage, and the need to educate farmers about proper use. For example, it has been claimed that in certain parts of India, the daily food borne intake of pesticide residues is approximately $0.51 \mathrm{mg}$ [8]. This is well above accepted levels, but the impact on public health and reproduction has not yet been fully investigated.

\section{Use of biopesticides (plant extracts)}

Many farmers in Asia and Africa have been using plant extracts such as neem (Azadiractha indica), wild tobacco (Calotropis procera) wood ash and dried chillies among others for controlling and repelling some insect pests [9]. The neem extracts have been reported to be broad-spectrum in activity, degrade rapidly to harmless 
metabolites and therefore, leave no residues in the environment where they are applied $[10,11]$. The use of neem extracts and other medicinal plants can form an important component of pest management strategies, especially in developing countries [12]. Many other scientists and farmers themselves have reported the use of crude or formulated plant pesticides in Asian and African countries [13, 14, 15]. In sub-Saharan Africa, the use of plant derivatives for pest control was said to have been common before the advent of synthetic pesticides, and the preparation and application of botanicals for crop protection for increased food production were linked to the folklores and tradition of the farmers [16]. According to the report of a survey of crop seed protection with botanicals carried out in Nigeria by Anjorin [17] the benefits of neem plant as source of pesticide include but not limited to the following: it is relatively cheap and easily available its possession of complex mixture of active ingredients which function differently on various parts of the insects life cycle that makes it difficult for pests to develop resistance to it. It is systematic, thereby protecting the plant from within. Neem has also been shown to be effective in controlling pathogens, Meloidogyne, root-knot nematode, Rhizoctonia, fungus and rice stunt virus [18]. Khalid and Shad [19] specifically reported that their toxic effect is normally of an ephemeral nature disappearing within $2-3$ weeks. Eze et al reported that ethanolic extracts of Azadiractha indica, Occimum gratissimum, Xylopia ethiopica and Zingiber officinale effectively inhibited population growth of weevils in stored yam chips and recommended that farmers should be educated on the economic and environmental benefits of botanical extracts [20]. Governments and development agencies in the developing world should therefore, encourage and promote the preparation and adoption of neem products at the farm level by resource poor farmers to protect their crops against insect pest infestation so as to ensure food security and safety

\section{Non-chemical pest management}

Common cultural practices that contribute to reduction in pest build-up include crop rotation, tillage, varying timing of planting or harvesting, planting trap crops and adjusting row width. Roller et al [21] stated that some insect pests and disease-causing organisms are hosts' specific giving example of how rice stem borer was controlled by planting other crops that were not attacked by the stem borer. It has been reported that tillage destroys pest's shelters and disrupt their life cycles, exposes pests to predators and unfavourable conditions, distributes soil nutrients throughout the soil, controls weeds and makes other cultural practices easier to undertake [22]. However, tillage disrupts the life cycle of other beneficial soil organisms and needs more labour cost for soil preparation among other disadvantages.

\section{Intercropping}

Intercropping is the cultivation of two or more crops simultaneously on the same field. It also means the growing of two or more crops on the same field with the planting of the second crop after the first one has completed its development. Facknath [23] noted that the rationale behind intercropping was that the different crops planted were unlikely to share the same insect pests and disease-causing pathogens. The report further noted that intercropping reduces the insect/mite pest population because of the diversity of crops grown when other crops are present in the 
field, the insect/mite pests become confused and they needed more time to look for favourable plant hosts.

\section{Trap cropping}

Trap cropping is the planting of a crop which could attract and harbour a pest(s) to protect main crop from a certain pest or several pests. Grundy and Short noted that trap cropping prevents pest attack that comes from all sides of the field and works best on pests that are found near the borderline of the farm [24]. Row intercropping could be achieved by planting in of the trap crop in alternating rows within the main crop. A planned trap cropping practice showing the trap crop and main crop, method of planting and pest control as demonstrated by Olkowski et al is shown in Table 1 [25].

\section{Pruning}

Pruning is the selective removal of specific plant parts like shoots and branches. Roots, flower buds, fruits, and seed pods can also be pruned. French and Appleton reported that pruning done on regular basis as part of plant care makes the plant less dense, improves the air circulation and sunlight penetration that decreased the incidence of pests and diseases and the conditions that promoted fungal growth and gets rid of the pest infested parts among others [31].

\section{Integrated Pest Management (IPM)}

Man in his efforts to destroy and or reduce his enemies (insect pests, rodents and pathogens) found that no one single method was perfect and even the very effective methods (chemicals) had negative effects on the quality (food safety) of food crops. A combination of all the known methods of pest control (integrated pest management) was adopted. Hoyt described integrated pest management (IPM) as an effective and environmentally sensitive approach to pest management that relies on a combination of common sense practices [32]. Sankoh noted that the quality of human life depends ultimately on the quality of the environment in which human lives and ability of this environment to provide food (food security), shelter and natural resources needed to generate employment and well secured life [33]. Since no single pest control method can guarantee food security and safety especially in Africa, IPM approach appears to bring hope but the impact in the rural farm communities is low. A research on integrated pest management adoption among farmers carried out in Nigeria by Ofuoku et al revealed that majority of the farmers (84.37\%) had not adopted IPM, while only $15.63 \%$ had adopted it [34] This according to the report could be because most of the farmers considered IPM as a computer technology that was not suitable for their own environment or not affordable at the moment. This is probably true because Agbamu had earlier reported that certain research findings, which were deemed to improve farm production, may be beyond the understanding of the rural farmers, even with the interpretation of the extension agents [35]. It is also probable that the availability of local pest control technique provided cheaper alternatives to improved one like IPM. 


\section{Government control programmes on food security and safety}

In United States, the U. S. Environmental Protection Agency (EPA) is responsible for a number of activities that contribute to food security within the United States in areas of food safety, water quality and pesticide application training. The EPA report showed that EPA is responsible for ensuring that the American Public is protected from potential health risks posed by eating foods that have been treated with pesticides [36]. In India, farmer field schools (FFSs) as reported by Amancini et al have been organized for a number of crops, and especially with the aim of reducing the massive use of pesticides in cotton production [37]. Women farmers in a selected sample of the cotton integrated pest management farmer field schools (IPMFFSs) were trained to identify the signs and symptoms of acute poisoning and to analyse the consequences of unsafe pest management behaviours [38]. Chin-wen et al reported that fifteen shipments of mangoes were rejected by Japanese inspectors, mainly due to detection of very low levels of cyfluthrin $(0.03 \sim 0.06 \mathrm{ppm})$ and cypermethrin $(0.04 \sim 0.07 \mathrm{ppm})$ [39]. The so-called "food quality" refers not only to external appeal, taste and freshness food safety is now the priority. Another example is in United Kingdom (UK) where the comprehensive database of farmers' practice with regard to fungicide and insecticide use on winter wheat is being examined to identify where farmers may be using pesticide programmes inappropriately. In view of the fact that pesticide usage may vary with farm size, this was achieved by grouping the farm into five classes as shown in table 2 [40]. This enabled government to select the proper number of farms in each group for visits, and avoid visiting large number of small farms which make little contribution to pesticide use or visiting large farms which contribute significantly.

\section{CONCLUSION}

The issue of food security and safety should be the responsibility of all stake-holders: the producer, middle man, government and the consumer. Therefore, all aspects of farm management such as sources of seeds and seedlings, pests and weed elimination, pesticide application, dates and amounts of fertilization, harvesting or post-harvest treatment and basic information regarding the individual farmer's activities should be closely monitored and made open to the general public. Food safety therefore, means that agro-products should undergo a certification process and be evaluated according to the Maximum Residue Limits (MRLs) adopted by the final user. 


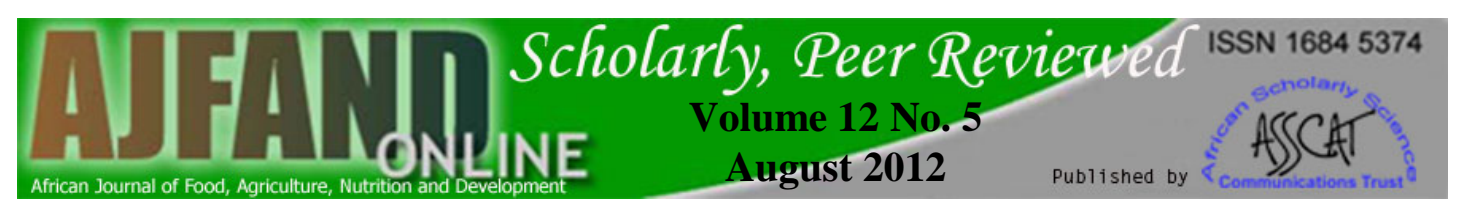

Table 1: Examples of trap cropping practices

\begin{tabular}{|c|c|c|c|}
\hline Trap crop & Main crop & $\begin{array}{l}\text { Method } \\
\text { planting }\end{array}$ & Pest controlled \\
\hline $\begin{array}{l}\text { Basil and } \\
\text { marigold } \\
{[26]}\end{array}$ & Garlic & Border crop & Thrips \\
\hline $\begin{array}{l}\text { Castor plant } \\
\text { [27] }\end{array}$ & Cotton & Border crop & Heliotis sp. \\
\hline $\begin{array}{l}\text { Chervil } \\
{[28]}\end{array}$ & $\begin{array}{l}\text { Vegetables } \\
\text { Ornamentals }\end{array}$ & Among plants & Slugs \\
\hline $\begin{array}{l}\text { Chinese } \\
\text { cabbage, } \\
\text { mustard, } \\
\text { and radish } \\
\text { [23] }\end{array}$ & Cabbage & $\begin{array}{l}\text { Planted in every } 15 \\
\text { rows of cabbage }\end{array}$ & $\begin{array}{l}\text { Cabbage webworm } \\
\text { Flea hopper } \\
\text { Mustard aphid }\end{array}$ \\
\hline $\begin{array}{l}\text { Chick pea } \\
\text { (Grundy; } \\
\text { Short, [24] }\end{array}$ & Cotton & $\begin{array}{l}\text { Block trap crop at } \\
20 \text { plants/ sq m }\end{array}$ & Heliotis sp. \\
\hline $\begin{array}{l}\text { Corn } \\
{[27]}\end{array}$ & Cotton & $\begin{array}{l}\text { Row intercrop, } \\
\text { planted in } \\
\text { every } 20 \text { rows of } \\
\text { cotton } \\
\text { or every } 10-15 \text { m }\end{array}$ & Heliotis sp. \\
\hline $\begin{array}{l}\text { Cowpea } \\
{[29]}\end{array}$ & Cotton & $\begin{array}{l}\text { Row intercrop in } \\
\text { every } \\
5 \text { rows of cotton }\end{array}$ & Heliotis sp. \\
\hline $\begin{array}{l}\text { Desmodium } \\
\text { [30] }\end{array}$ & $\begin{array}{l}\text { Corn } \\
\text { Cowpea } \\
\text { Millet } \\
\text { Sorghum }\end{array}$ & Row intercrop & $\begin{array}{l}\text { Stemborer } \\
\text { Striga }\end{array}$ \\
\hline $\begin{array}{l}\text { Onion and } \\
\text { garlic }\end{array}$ & Carrot & $\begin{array}{l}\text { Border crops or } \\
\text { barrier } \\
\text { crops in between } \\
\text { plots }\end{array}$ & $\begin{array}{l}\text { Carrot root fly } \\
\text { Thrips }\end{array}$ \\
\hline Sickle pod & Soybean & Strip intercrop & $\begin{array}{l}\text { Velvet bean } \\
\text { caterpillar } \\
\text { Green stink bug }\end{array}$ \\
\hline Soybean & Corn & Row intercrop & Heliotis sp. \\
\hline $\begin{array}{l}\text { Sudan grass } \\
\text { [30] }\end{array}$ & Corn & $\begin{array}{l}\text { Intercrop } \\
\text { Border crop }\end{array}$ & Stemborer \\
\hline
\end{tabular}




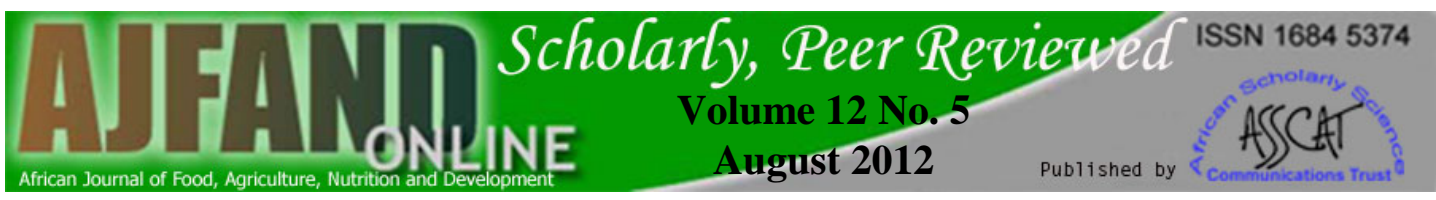

Table 2: Size grouping, number of farms and total area for arable farms in England and Wales

\begin{tabular}{|l|l|l|l|l|l|l|}
\hline & $<50 \mathrm{Ha}$ & $50-100 \mathrm{Ha}$ & $\begin{array}{l}100- \\
150 \mathrm{Ha}\end{array}$ & $\begin{array}{l}150- \\
250 \mathrm{Ha}\end{array}$ & $>250 \mathrm{Ha}$ & Total \\
\hline $\begin{array}{l}\text { Area of } \\
\text { farm }\end{array}$ & 687,118 & 710,797 & 550,187 & 719,954 & 940,621 & $3,608,679$ \\
\hline \% by area & 19 & 20 & 15 & 20 & 26 & 100 \\
\hline $\begin{array}{l}\text { Number of } \\
\text { farm }\end{array}$ & 39,629 & 9,972 & 4,502 & 3,786 & 2,367 & 60,256 \\
\hline
\end{tabular}

Source: Guidelines for the collection of Pesticide Usage statistics with Agriculture and Horticulture by Miles R. Thomas 


\section{REFERENCES}

1. Youdeowei A Pest and vector management in the tropics, Longman Nigeria PLC.1995; 52 Oba Akran Avenue, Ikeja Lagos, Nigeria

2. Koirala PS, Dhakal PD and AS Tamrakar Pesticide application and food safety issue in Nepal 2009.

3. FAO. The State of Food Insecurity in the World High food prices and food security threads and opportunities 2008; (available at http://www.fao.org/docrep/011/i0291e/i0291e00.htm

4. Rosegrant MW, Huang J, Sinha A, Ahammad H, Ringler C, Zhu T, Sulser TB, Msangi $\mathbf{S}$ and $\mathbf{M}$ Batka Exploring Alternative Futures for Agricultural Knowledge, Science, and Technology Persley). Wallingford: CAB International 2008

5. Oerke EC Crop losses to pests. Journal of Agricultural Science 2006; 144: 31-43. Cambridge University Press

6. FAO. Climate change: Implications for food safety. 2008b (available at http://www.fao.org)

7. Schillhorn TW Agricultural Pest Management at a Crossroads: New Opportunities and New Risks. The World Bank1818 H Street N.W. Washington D.C. 1999; 20433, USA.

8. Alam G Biotechnology and Sustainable Agriculture. Lessons from India. Technical paper 103. Paris1994; OECD Development Center

9. Ahmed S, Naseer A and S Fiaz Comparative Efficacy of Botanicals and Insecticides on Termites in Sugarcane at Faisalabad. Pak Entomol 2005; 27 No. 1

10. Schmutterer $\mathbf{H}$ Properties and potentials of natural pesticides from the Neem tree. Annual Review of Entomology 1990; 35: 371-298.

11. Deka MK and SN Singh Neem formulation in the management of sugarcane insects and pests. Procceding $63^{\text {rd }}$ Ann. Conv. Sugar Technol, Associ. 27 - 29 August , Jailpur, India 2001; 33-38

12. Obeng-Ofori D and DA Ankrah Effectiveness of Aqueou Neem Extracts for the Control of Insect Pests of Cabbage (Brassica oleracea var capitata L) in Accra Plains of Ghana. Agric. and Food Sc. J. of Ghana 2002; 1 (1): 83-94.

13. Tsado EK and MA Tanko Evaluation of three local plants for the control of Storage insect pests of maize and cowpea. Paper presented at the $30^{\text {th }}$ Annual Conference of the Nigerian Society for Plant Protection, University of Agriculture, Abeokuta. Sept. 2002; 1-4. 
14. Tang'an BNS, Adebitan SA, Adbul SD and JA Ogidi Fungicide activity of some plant extracts on Cercosporea sojina Hara: the causal agent of frogeye leaf spot of soybeans. Paper presented at the $30^{\text {th }}$ Annual Conference of the Nigerian Society for Plant Protection, University of Agriculture, Abeokuta. Sept. 2002; 1-4.

15. Anjorin ST, Salako EA and RW Ndana In vitro assessment of some plant leaf extracts for the control of Meloidogyne spp and Rhizoctonia solani Zuma J. Pure Appl. Sci. 2004; 7: (1).

16. Saxena K Indigeneous crop protection practices sub-Saharan East Africa. In: Database of Natural Crop protectant Chemicals (DNCPC) 1987; Available at http: www.ipmafrica.htpm

17. Anjorin ST A survey of crop seed protection with botanicals in the FCT Abuja, Nigeria. J. Sustainable Trop. Agric. Res. 2008;Vol. 24.

18. Anonymous Neem: A tree for solving global problems. Report of an Ad-hoc panel of the Board of Science and Technology for International Development, National Research Council, national Academy Press. Washington D. C. 1992.

19. Khalid $\mathbf{S}$ and RA Shad Potential advantage of recent allelochemical discovery and agro-ecosystems. Prog. Farm. 2002; 11: 30-35.

20. Eze SC, Asiegbu JE, Mbah BN, Orkwor GC and R Asiedu Effects of Aqueous and Ethanolic extracts and concentration of four agrobotanicals and gibberrelic acid $\left(\mathrm{GA}_{3}\right)$ on the shelf life of the White Guinea yam Dioscorea rotundata. Bio-research J 2006; 4: 67-73

21. Roller E and HF Poehling Ecological infrastructures Ideal book on functional biodiversity at the farm level. IOBC, OILB, Mattenbach AG. Winterthur, Switzerland 2004.

22. FAO. Training modules on conservation agriculture. Land and Water Digital Media Series \# 22. Food and Agriculture Organization, Viale delle Terme di Caracalla, Rome, Italy.2002

23. Facknath S Application of neem extract and intercropping for the control of some cabbage pests in Mauritius. Proc. International Neem Conference, Queensland, Australia, Feb. 2000.

24. Grundy PSS Potential alternative to chickpeas for trap cropping. ANP Technology, Green mount Press. DPI, Queensland. 2003; 22: (1) p. 14

25. Olkowski W, Daar S and H Olkowski The gardener's guide to commonsense pest control. The Taunton Press USA 1995.

26. MMSU. Seven new botanical extracts vs. garlic pests. Mariano Marcos State University. Batac, Ilocos Norte, Philippines 2003 
27. Hasse V Cotton. No 1-2. Philippine-German Cotton Project, Department of Agriculture. Manila, Philippines 1987.

28. Ellis B and F Bradley The organic gardener's handbook of natural insect and disease control. Rodale Press. Emmaus, Pennsylvania 1996.

29. CIKS. Bollworm control in cotton. Center for Indian Knowledge Systems. Chennai, India. Pesticide Post. 2000; 8: No 6.

30. ICIPE. Scientific Report. International Center for Insect Physiology and Entomology, Nairobi, Kenya. 2003.

31. French S and B Appleton A guide to successful pruning: Pruning basics and tools. Ornamental and Turf. Virginia Cooperative Extension, Virginia Polytechnic Institute and State University. Publication 2001; 430-455.

32. Hoyt B Integrated Pest Management (IPM) and Food production: Communication Services, Branch Office of Pesticide Programmes, U. S. EPA. 1200 Pennsylvania Ave, NW Washington, DC 2001; 20460 (703): 305-5017

33. Sankoh OA. Environmental Assessment and Management. Afric. J. of Environ. Managment. 1999; 1 (1): 3-10

34. Ofuoku AU, Egho EO and EC Enujeke Integrated Pest Management (IPM) adoption among farmers in central agro-ecological zone of Delta State, Nigeria. African J. of Agric Res. 2008; 3 (12): 852 - 856.

35. Agbamu JU Essentials of Agricultural Communication in Nigeria Lagos: Malthouse Press Ltd. 2006.

36. EPA The EPA and Food Security 2007; available at http://www.epa.gov/pesticides/food/ipm.htm.

37. Amacini FH, Ariena C and V Bruggen Evaluating cotton integrated pest Management (IPM) Farmer Filed School using the sustainable livelihoods Approach in India. Expl. Agric. 2007; 43: 97-112.

38. Mancini F, Bruggen V, Jiggins AHC, Ambatipudi LSJ and H Murphy Acute pesticide poisoning of cotton growers in Andhra Pradesh. International Journal of Occupational and Environmental Health; 2005; 11:221-232.

39. Chin-Wen K, Tuan S and $\mathbf{L}$ Hong-Ping Safety Management and Inspection of Agro-chemical Residues of Food in the Trade of Export Products: A case study of the Taiwan Grown Irwin mango. Taiwan Agricultural Chemicals and Toxic Substances Research Institute (TACTRI) 11 Kung Rd., Wufeng, Taiwan Roc, 2009; 04-07

40. Thomas MR UK Ministry of agriculture, Fisheries and Food central Science Laboratory for the Eurostat Pesticide Statistics Task force, 1999. 